\title{
IAPB E SINDICATO: DUAS ESTRUTURAS INTERLIGADAS
}

\author{
Ana Lúcia Oliveira \\ Universidade Federal Rural do Rio de Janeiro
}

\begin{abstract}
RESUMO
O objetivo deste artigo é analisar as relações entre o Instituto de Aposentadorias e Pensões dos Bancários $(I A P B)$ e o sindicalismo bancário. Nossa tese é a de que os bancários, através do sindicato, apropriaram-se desse espaço para intervir diretamente na política de previdência social, diferentemente de outras categorias como a dos industriários.
\end{abstract}

PALAVRAS-CHAVE: bancários; sindicato; sindicalismo; Instituto de Aposentadorias e Pensões dos Bancários (IAPB).

\section{INTRODUÇÃO}

Junto com a criação de uma legislação regulamentando as relações trabalhistas, o Estado brasileiro implementou, a partir de 1930, uma política de ampliação dos serviços de assistência e previdência social, dando início aos Institutos de Previdências Sociais (IAPs). Cabe observar que, até então, esta era uma questão restrita ao setor privado, através de contratos de seguros efetivados entre empregador e empregados.

De acordo com Paul Erickson (1970, p. 5657), o sistema de previdência social fazia parte da política trabalhista fomentada nos anos trinta, formando um tripé com os sindicatos corporativos e a Justiça do Trabalho. Cabia à previdência social garantir o bem estar social através da contribuição tripartite do Estado, dos empresários e dos trabalhadores (apud ALMEIDA, 1975, p.50).

Para Amélia Cohn, essa interdependência não se manifestava apenas no nível da organização e do entrelaçamento que a política estatal do período iniciado com a Revolução de Trinta criara, mas se refletia também na atuação específica dos sindicatos e das instituições previdenciárias. "Sindicatos mais atuantes estão estreitamente relacionados com uma melhor cobertura previdencial, e vice-versa. E, em assim ocorrendo, a previdência social passa também a ser elemento de mobilização política" (COHN, 1980, p. 19).

A idéia de complementaridade entre sindicato e previdência social a partir da Revolução de Trinta também é compartilhada por James M. Maloy. Para este autor, sob o governo Vargas, a política previdencial foi retomada como parte de uma visão sistematizada a respeito das relações trabalhistas em geral e convertida em um importante instrumento de controle estatal. Por ter sido usado pelo governo como instrumentos de cooptação e controle, o sistema de previdência social não pode ser estudado isoladamente. Para compreendê-lo em toda sua dimensão, será necessário tomá-lo como parte crucial do complexo jogo entre o Estado e a classe trabalhadora (MALOY, 1976, p. 121).

Em que pesem tais assertivas, o presente estudo se propõe a trilhar um caminho menos explorado: correlacionar a legislação previdencial com o processo de estruturação do sindicalismo bancário. Nosso objetivo é demonstrar como o Instituto de Aposentadorias e Pensões dos Bancários (IAPB), desde sua fundação em 1934 até sua extinção em 1966, constituiu-se em importante instrumento político e fonte de poder para as lideranças sindicais bancárias. Além disso, consideramos que o IAPB serviu de canal para uma disputa entre o Partido Comunista - grupo dominante na categoria - e outros setores bancários, constituindo-se, portanto, num elemento decisivo para a consolidação do sindicalismo corporativo de Estado.

Sobre o tema, a literatura existente, não raras vezes, vinculou automaticamente legislação sindical e legislação previdencial. De fato, ambas 
são parte de um mesmo projeto trabalhista. No entanto, suas estruturas diferenciadas se traduzem em aspectos específicos cuja relação nem sempre é perceptível e simples.

Com efeito, os Institutos, ao contrário dos sindicatos, foram organizados como entidades centralizadas nacionalmente, enquanto os sindicatos eram entidades municipais. Além da organização em nível nacional, e mais importante, os Institutos não seguiram à risca, como os sindicatos, a estrutura das categorias profissionais. Dessa forma, enquanto em relação ao movimento sindical o governo estabeleceu uma organização rigidamente vertical e municipal, na previdência buscou a unificação horizontal e nacional.

Tanto houve Institutos organizados por categorias profissionais como, por exemplo, dos bancários, marítimos, comerciários, entre outros; quanto por setor econômico, como foi o caso do Instituto de Aposentadorias e Pensões dos Industriários (IAPI), que rompeu com a divisão em categoria profissional e aglutinou, em um mesmo Instituto, trabalhadores de todo um setor econômico, genericamente chamado de "industriários".

Apesar destas diferenciações, não há dúvida que ambas as estruturas - sindicatos e institutos - faziam parte de um mesmo e único projeto. Resta identificar como se articularam, e mais, em que sentido a criação dos Institutos foi importante para a consolidação do sindicalismo corporativo.

Neste artigo estudaremos o IAPB como elemento determinante na consolidação do sindicalismo bancário, analisando-o sob dois aspectos. $\mathrm{O}$ primeiro deles nos remete à simbiótica relação das duas estruturas desde suas origens. O IAPB foi criado, em parte, porque, se genericamente havia a proposta de uma legislação previdencial feita pelo governo, sua implementação se deu pela grande pressão e mobilização da categoria, através do sindicato ${ }^{1}$. Desde então, foi permanente a tensão entre o governo e as lideranças sindicais acerca dos rumos a serem seguidos pela instituição.

O segundo aspecto decorre das características apontadas acima, embora seja um fato menos estudado. O IAPB tornou-se um poderoso recurso de poder das lideranças sindicais em suas relações

\footnotetext{
1 O IAPB foi criado no bojo da greve de 1934 . Sobre a greve ver OLIVEIRA,1998, p. 185-202.
}

com a categoria. Através dele, muitas conseguiam consolidar-se, tornando bastante difícil a vitória de oposições com possibilidade de vitória. Convém ressaltar que não estamos absolutizando a prática sindical de intervenção política no IAPB como único elemento de sustentação das direções, mas certamente este foi um elemento importante.

\section{PREVIDÊNCIA SOCIAL E SINDICATO ASSISTENCIAL}

O seguro social sempre foi uma reivindicação histórica do movimento operário brasileiro ${ }^{2}$. Instituído ainda nos anos vinte pela Lei Elói Chaves (1923), que criou as Caixas de Aposentadorias e Pensões para os empregados em estradas de ferro, e estendido pelo decreto $\mathrm{n}^{\circ} 5.109$ (1926), as CAPs tinham por objetivo prestar serviços assistenciais e previdenciários: o artigo nono do Regulamento da Caixa dos Ferroviários dava direito: " $1^{\circ}$, a socorros médicos em casos de doenças em sua pessoa ou pessoa de sua família, que habite o mesmo teto e sob a mesma economia; $2^{\circ}$, a medicamentos obtidos por preço especial determinado pelo Conselho de Administração; $3^{\circ}$, a aposentadoria; $4^{\circ}$, a pensão para seus herdeiros em caso de morte" (MELLO, 1981, p. 05).

As CAPs eram organizadas por empresa e possuíam o caráter de seguro privado: o trabalhador adquiria o direito ao benefício mediante contribuição financeira. Neste sentido, o direito esgotavase pela interrupção no pagamento ou até mesmo quando o empregado mudava de empresa (GOMES, 1983, p. 289).

Com Vargas, sem eliminar inicialmente o sistema de caixas, foram criados os IAPs. O núcleo básico de filiação deixou de ser voluntário e por empresa, passando a ser compulsório e, na maioria dos casos, envolvendo todo um setor econômico. Note-se que não era proposto um sistema universal de seguridade, mas um sistema restrito aos trabalhadores com carteira assinada que passavam a ter o direito de contribuir e receber benefícios e assistência.

O financiamento das CAPs e dos IAPs era tripartite, variando na forma e nos percentuais de acordo com cada caso. Foi na forma de administração dos IAPs onde houve maiores mudanças.

\footnotetext{
2 Sobre as reivindicações ver OLIVEIRA e TEIXEIRA 1986, p. 53-57.
} 
A administração das Caixas era feita por um Colegiado formado por um número igual de representantes dos empregados e empregadores. O Estado não tinha qualquer participação na gerência destas instituições. Já nos Institutos, o presidente da entidade era escolhido pelo poder público, sendo assistido por um Conselho Administrativo. Ou seja, os IAPs eram órgãos diretamente ligados ao Estado (COHN, 1980, p. 06).

No texto constitucional de 1934, foi assegurado que os Institutos deveriam prestar serviços assistenciais e previdenciários ${ }^{3}$. A difusão dos benefícios, bem como sua regulamentação, no entanto, não foi uniforme. Em geral, ficou na dependência do poder de cada categoria profissional. Além disto, a implementação dos IAPs reforçou as disparidades econômicas existentes entre as diferentes categorias profissionais, porque a qualidade e o volume dos serviços e benefícios prestados pelas instituições, dependiam, além das articulações políticas mais gerais, da capacidade de financiamento de cada categoria 4 .

No projeto do governo, em distinção à Constituição de 1934, os Institutos eram responsáveis apenas pelos benefícios previdenciários - pensões e aposentadorias - enquanto os serviços assistenciais - médicos, odontológicos etc. seriam prestados apenas se houvesse disponibilidade financeira (OLIVEIRA e TEIXEIRA, 1986 , p. 65). No projeto corporativo, cabia portanto, aos sindicatos, a função de prestar serviços assistenciais, como estava definido no Artigo $5^{\circ}$ da lei de sindicalização de 1931: "Art. $5^{\circ}$ ) Além do direito de fundar e administrar caixas beneficentes, agências de colocação, cooperativas, serviços hospitalares, escolas e outras instituições de assistência, [...]" (BRASIL. Decreto no 19.770, 19/03/ 1931).

Este fato explica, por exemplo, porque o decreto $\mathrm{n}^{\circ} 24.615$ de 09/07/34, que criou o IAPB, um pouco antes da Constituição, foi bastante

\footnotetext{
3 A Constituição assegurou, entre outras coisas, a licença maternidade, aposentadoria por velhice, invalidez, acidente de trabalho, indenização em caso de morte etc.

4 Já que as contribuições eram um percentual dos salários dos empregados, aquelas categorias com níveis salariais mais altos obtinham mais recursos para seus institutos, como era o caso dos bancários, comerciários e servidores públicos (COHN, 1980, p. 09).
}

restritivo em relação à assistência médica e complementar: "Art. $1^{\circ}$ ) Fica criado, com a qualidade de pessoa jurídica e sede na Capital da República, o Instituto de Aposentadoria e Pensões dos Bancários, subordinado ao Ministério do Trabalho Indústria e Comércio, por intermédio do Conselho Nacional do Trabalho, e destinado a CONCEDER aos seus associados os benefícios da aposentadoria e aos herdeiros o da pensão. Parágrafo $1^{\mathrm{O}}$ - Além dos benefícios previstos neste artigo, poderá o Instituto manter serviços de assistência médica, cirúrgica e hospitalar, subordinados à regulamentação especial, enquanto não houver legislação relativa a essa fórmula de assistência social" (INSTITUTO DE APOSENTADORIAS E PENSÕES, 1935; sem grifos no original).

O projeto previa, portanto, duas estruturas complementares e competitivas: uma de assistência e outra de previdência. A divisão foi objeto de grandes pressões e gerou uma permanente tensão entre os Institutos e os sindicatos; um tentando transferir para o outro as funções assistenciais. Até pelo menos a introdução do imposto sindical, os sindicatos não tinham a menor possibilidade prática de assumir o serviço assistencial. Apenas depois de sua implantação, as relações entre os Institutos e os sindicatos, na maior parte dos casos, tornaram-se complementares. Mesmo assim, os sindicatos sempre tentaram repassar os serviços assistenciais, reduzindo o comprometimento de seus recursos com estas atividades. No caso dos bancários, os sindicatos conseguiram que o IAPB assumisse a maior parte das necessidades assistenciais da categoria ${ }^{5}$.

Apesar das tentativas constantes do governo em reduzir a abrangência dos serviços assistenciais, o sindicato dos bancários manteve sua posição de manter no IAPB as despesas com o assistencialismo: "Quanto ao conhecimento da reforma do Instituto dos Bancários, à melhoria e à fiscalização dos seus serviços, à ampliação dos seus benefícios, à defesa da instituição em si, como órgão de assistência e previdência da classe, cuja criação foi uma de suas formidáveis conquistas, quanto à repulsa à sua projetada fusão com outros Institutos e qualquer outra medida que se tornasse prejudicial

\footnotetext{
5 No campo da assistência médica, a única exceção foram os serviços odontológicos. No entanto, mesmo estes os sindicatos reivindicavam que passassem a serem prestados
} pelo IAPB. 
aos interesses dos bancários, como a abolição de alguns dos seus atuais serviços ou à prestação de quotas adicionais, é claro serem pontos essenciais do nosso programa, simples reavaliação do programa das administrações passadas" (HOCHMAN, 1990, p. 87; sem grifos no original).

Outro ponto de atrito entre o sindicato e o governo, não só por ocasião da criação do IAPB, mas durante as mais de três décadas de sua existência, foi a rejeição às tentativas de unificação dos Institutos. No primeiro projeto do governo os bancários estavam enquadrados junto com os comerciários, no IAPC. Fazendo um intenso lobby, conseguiram diferenciar-se. Depois de 1945, no fim do Estado Novo, o governo tentou criar o ISSB - Instituto de Serviços Sociais do Brasil -, unificando todas instituições previdenciárias. Com a queda de Vargas, no entanto, o projeto não teve andamento. No período seguinte, que vai até 1960 , foram feitas várias outras tentativas de fusão progressiva. A mais importante foi a aprovação, em 1960, da Lei Orgânica da Previdência — LOPS —, durante o governo Juscelino. A LOPS não unificou os Institutos, porém conseguiu dar um passo importante neste sentido ao uniformizar as contribuições e benefícios. De acordo com a mesma, foi instituída uma administração colegiada para cada Instituto e o Conselho de Administração passou a ser composto por um número igual de empregados, empregadores e representantes do governo, onde a presidência deveria ser alternada entre os membros do Conselho (COHN, 1980, p. 11-16; HOCHMAN, 1990, p. 189-198).

A oposição à unificação do sistema previdenciário por parte das direções bancárias foi uma constante em todo o período estudado. De todos os projetos apresentados para a reforma da previdência, o único que teve o apoio das direções bancários foi o da Lei Orgânica da Previdência, mesmo assim porque passou por um intenso debate no Congresso Nacional e entre as direções sindicais nacionais que, inclusive, apresentaram diversas emendas que foram incorporadas ao projeto aprovado (Bancário, jan/fev, 1959). O apoio dos bancários à LOPS deveu-se ao estabelecimento da administração colegiada, que seria composta por igual número de representantes dos empregados, empregadores e do governo que se revezariam na presidência do Instituto. Esta forma de administração consagrou a participação dos trabalhadores na gestão e aplicação dos recursos de todos os Institutos, o que garantiu o apoio de seto- res, como os bancários, tradicionais opositores às reformas no sistema previdenciário.

De acordo com James M. Maloy, a resistência dos bancários à unificação e às reformas do sistema de previdência se deveu ao fato de ela redundar em perdas das vantagens dessa categoria profissional. Para ele, na medida em que, em termos de eficiência tanto no atendimento aos pedidos de aposentadorias e pensões, quanto na prestação dos serviços assistenciais, o IAPB destacava-se dos outros Institutos (1976, p. 115) ${ }^{6}$.

Já Letícia Bicalho Canêdo propõe uma explicação que, a nosso ver, complementa a análise acima. A autora afirma que o empenho dos sindicatos de bancários na administração dos Institutos advém da necessidade de sobrevivência política dos próprios sindicatos, sendo esse um fator determinante da eficiência do IAPB (1978, p. 158).

Se é verdade que essas questões relacionamse com a própria trajetória histórica das lutas da categoria bancária por seu Instituto, por outro lado, não é menos certo que, saindo vitoriosa na disputa por uma maior participação na administração do seu Instituto e pela ampliação dos seus serviços, acabou por delinear profundas diferenças com as demais experiências. Desta forma, podemos afirmar que a unificação feita em 1966-67 significou uma grande derrota para os bancários. Segundo eles próprios, ocorreu um "nivelamento por baixo" que afastou as lideranças sindicais da gestão da previdência social e, portanto, de seus recursos (Bancário, 31/05/1967, p. 11; Bancário, 30/06/1967). Com efeito, desde a sua fundação e durante toda a sua existência, o sindicato esteve intimamente ligado ao IAPB, seja intervindo diretamente em sua administração, através da militância dentro dos quadros do Instituto, seja através de pressões e mobilizações da categoria para exigir a manutenção de direitos ou a ampliação de serviços.

Segundo Hochman, foi neste jogo político de afirmação do modelo corporativista e da capacidade de pressão de determinados sindicatos, que acabou por ser consolidada a estrutura dos IAPs.

6 Para se ter uma idéia da qualidade dos serviços prestados pelo IAPB, em 1966, quando houve a unificação dos Institutos, esta autarquia atendia a cem por cento da demanda por serviços médicos de seus associados, enquanto que 0 IAPI atendia somente a trinta por cento (COHN, 1980, p. 23). 
Marítimos, bancários, comerciários, negociando com o governo ou recorrendo à greve alcançaram seus Institutos, com características de previdência e assistência, indo contra o modelo inicialmente proposto pelo Estado, que era basicamente previdenciário.

\section{IAPI COMO MODELO IDEAL, O IAPB COMO PRÁXIS}

Confrontar as experiências do IAPI com as do IAPB é uma forma elucidativa de entendermos a distância que os separou. O primeiro nasceu e extinguiu-se como um organismo eminentemente técnico e pouco sujeito às pressões políticas, especialmente dos sindicatos e categorias, ganhando vida própria, sob uma direção burocratizada e voltada mais a atender seus próprios interesses. Já o IAPB foi construído em paralelo com o sindicalismo bancário. Assim, mesmo tendo se formado uma burocracia diretiva, ela esteve, ao longo de sua existência obrigada a responder tanto às lideranças sindicais, quanto à própria categoria que via o Instituto como "seu".

O IAPI foi implantado como um "modelo ideal". Ele concentrava várias categorias distintas em um único Instituto e seguia exatamente o projeto do governo, concedendo apenas pensões e aposentadorias. Foi criado por lei aprovada pela Câmara de Deputados ${ }^{7}$ e começou a funcionar em 1938, já no Estado Novo. A lei não definiu em detalhes a forma de organização e funcionamento, mas remeteu esta questão para uma comissão encarregada de estudá-los do ponto de vista técnico e racional.

O governo justificou a existência de um corpo técnico de excelência no Instituto por algumas razões básicas: a) pelo desejo de tornar o IAPI uma organização padrão para a administração pública; b) pelas dificuldades da tarefa de montar um Instituto nas suas proporções, onde estaria previsto um grande número de beneficiários. Seria necessário, portanto, restringir a abrangência dos serviços assistenciais, alocando os recursos prioritariamente para pensões e aposentadorias (HOCHMAN, 1990, p. 28).

Além disto, em correspondência ao Presidente Getúlio Vargas, o ministro Waldemar Falcão

7 Foi o único instituído por lei (BRASIL. Lei n o 367, de 31 de dezembro de 1936). sugeriu que os técnicos assumissem o IAPI “[...] indispensável [...] que a testa dos seus principais serviços, para a segurança da fiel execução do plano maduramente elaborado se colocassem técnicos reconhecidamente idôneos, possuidores das qualidades necessárias para iniciarem sem dificuldades nem deslizes os trabalhos delineados e colaborassem com a sua experiência para o completo êxito do programa sabiamente traçado" (apud HOCHMAN, 1990, p. 87).

Assim, O IAPI foi organizado dentro de um conjunto de normas racionais com a participação de técnicos do Ministério do Trabalho, Indústria e Comércio, que acabaram por monopolizar o discurso sobre a previdência social e passaram a ocupar postos chaves na sua direção. Essa equipe, que se cristalizou na direção, tornou-se uma referência para qualquer tema relacionado à previdência social.

Todo o sistema de arrecadação e contabilização do IAPI foi pré-organizado, o material padronizado, inclusive prevendo-se o processamento eletrônico de dados. O quadro de funcionários foi escolhido através de concurso público. Por isso, o Inapiário "não devia nada a ninguém, porque tanto conquistava seus cargos através da competência demonstrada em concurso como seu Instituto fora fruto da afirmação da técnica sobre a política" (HOCHMAN, 1990, p. 64) ${ }^{8}$.

A direção do IAPI se "apresentava" como um fato novo na administração pública brasileira. No entanto, essa diferenciação foi articulada tão precocemente que os textos de preparação para o primeiro concurso de seleção de funcionários já apresentava o IAPI e sua gênese como um novo caminho para o setor público. Apontavam para o fato de que a própria história da previdência social poderia ser revista a partir dele (cf. HOCHMAN, 1990, p. 64)

O tecnicismo que predominou na constituição do IAPI, como considerou Hochman, tornou-o pouco sensível às ingerências políticas e pressões dos sindicatos e mesmo dos seus contribuintes.

8 Inapiário foi originalmente 0 título da revista do IAPI que tinha como "objetivo a integracão dos funcionários através da criação e reforço de uma identidade denominada de inapiária. 0 sucesso do projeto da revista, resultou na incorporacão pelo corpo de funcionários da autodenominação como inapiários" (HOCHMAN, 1990, p. 64ss). 
Mas isto não se traduziu em maior eficiência, ao contrário do que era propagandeado. $\mathrm{O}$ discurso de competência e mérito, encobria a enorme e reconhecida ineficiência na prestação de serviços assistenciais, assim como na fiscalização à sonegação por parte dos empresários. O IAPI esteve, portanto, muito mais voltado para atender aos interesses do seu corpo de funcionários, do que dos industriários e seus dependentes ${ }^{9}$.

O depoimento de Lauro Jurandyr de Castro Leão, dirigente sindical e dirigente do IAPB, expressa esta inoperância "[...] todo funcionário que entrava para lá era concursado, era gente competente, mas eles não foram para lá com o propósito de servir aos trabalhadores, ao segurado, ao dono. Eles se organizaram lá dentro, pensando que aquilo era deles. Para o funcionalismo, aquilo funcionava que era uma maravilha! Agora, para o trabalhador, nunca funcionou. Foi um desastre. Basta dizer, para citar um exemplo, que foi lá que criaram a patronal" (LEÃO, 1986, p. 65).

Ao contrário do IAPI, o IAPB teve uma gestão eminentemente política e, portanto, sujeita ao controle e pressão pela mobilização dos associados. Em diversos depoimentos, os segurados afirmam que o nível de assistência e benefícios concedidos pelo IAPB eram mais amplos e de melhor qualidade.

O IAPB foi o resultado da grande pressão dos bancários sobre o governo, e teve sua origem ligada à primeira greve nacional dos bancários. Este fato marcou as relações entre governo/IAPB/ bancários durante toda sua existência. Mais do que mera retórica, isso é constantemente lembrado pelas diretorias sindicais: “As intrigas não destroem os fatos [...]. Com referência às inverdades ora veiculadas na classe bancária sobre supostas atitudes do sindicato do Rio contra o Instituto e sua administração [...]. Sem falsa modéstia, somos forçados a declarar que o IAPB é em grande ou na maior parte obra do Sindicato do Rio de Janeiro. [...] foi o Sindicato do Rio, foram os seus

9 Os funcionários do IAPI ao contrário dos do IAPB que eram atendidos pelo próprio Instituto, possuíam, entre outros benefícios, a "Assistência Patronal", que era uma empresa de seguro social para prestação de serviço médico exclusivamente aos servidores do IAPI e seus dependentes. Este programa de assistência médica teve início no final de 1945, enquanto que o serviço de assistência médica do IAPI para os associados só começou a funcionar em 1950, e mesmo assim de forma bastante limitada (ibidem, p. 167-170). dirigentes, os principais autores do decreto-lei 24.615, [Decreto que criou o Instituto] e foi também o Sindicato do Rio que colaborou na feitura do regulamento do Instituto, baixado com o decreto n ${ }^{\circ} 54$ " (Bancário, jun./1943, p. 10-11).

Ainda em 1967, as direções sindicais mantinham o mesmo tom do discurso: "O nosso Instituto IAPB, não foi dádiva, foi conquista da greve de 1934 que o arrancou do governo[...]" (Bancário, 30/06/1967, p. 06).

A ligação entre o sindicato e o Instituto era tão umbilical, que a primeira administração do IAPB teve a participação direta do sindicato. De acordo com o depoimento de Luís Viegas, antes mesmo de ser regulamentado e por iniciativa do sindicato, os funcionários e militantes sindicais foram cedidos para a estruturação e organização do IAPB (LIMA, s/d, p. 33). É o que diz também Lauro J. de Castro Leão: “[...] Quando foi criado, o funcionalismo do IAPB saiu do sindicato, eram indicados até parentes de bancário. Era como se fosse uma família só. O pessoal lá de dentro tinha ligação até de grau de parentesco com o bancário. Quer dizer, fazia-se isso justamente para manter esse vínculo" (LEÃO, 1986, p. 20-21).

$\mathrm{O}$ entrelaçamento entre as estruturas sindical e do Instituto extrapolava as relações formais e políticas e chegava a estabelecer ligações "sangüíneas" entre eles, no seu artigo trigésimo quarto, onde garantia preferência em sessenta e seis por cento dos postos de trabalho no IAPB a bancários, seus filhos ou irmãos (BRASIL. Decreto n ${ }^{\circ} 24.615$, 1935; BRASIL. Decreto $\left.n^{\circ} 54,1935\right)$.

A influência das direções sindicais nas contratações, aproveitando-se bancários demitidos ou desempregados, aposentados e familiares, deu-lhes enorme poder junto à categoria. Ao dar emprego, estabeleciam vínculos de gratidão, traduzidos em dívida política. Por outro, ao colocar "apadrinhados", abriam canais informais de influência no atendimento dos segurados.

No próprio regulamento, redigido com a participação do sindicato, há um artigo lapidar sobre esta questão: "os lugares de empregados do Instituto serão providos mediante concurso, reservando-se à administração o direito de livre escolha entre os habilitados" (BRASIL. Decreto $\mathrm{n}^{\circ} 24.615$, artigo 33, 1935, sem grifos no original).

Essa ingerência sindical sobre o IAPB se deu por uma intensa pressão sobre o governo. Em pleno 
debate da Assembléia Nacional Constituinte, no final de 1933, o Ministério do Trabalho encaminhou aos sindicatos, inclusive ao dos bancários, um anteprojeto para a criação de um instituto de previdência. Este era um dos temas que mais sensibilizava a categoria, pois envolvia a assistência médica e a aposentadoria. Os bancários não tinham nenhuma legislação social de proteção em caso de doença, invalidez, morte ou velhice; este, aliás fora um dos motivos para a organização do sindicato e seu fortalecimento.

Os bancários já vinham discutindo o assunto desde 1932. Há algum tempo, haviam solicitado à Organização Internacional do Trabalho (O.I.T.) em Genebra, pareceres e, especialmente, leis em vigor em outros países. O material enviado foi examinado no início de 1933 e motivou uma nova reunião com os sindicatos de São Paulo e Santos. O resultado foi a rejeição da proposta do governo (MOURA, 1989). Além dos bancários, também os marítimos rejeitaram os anteprojetos oficiais.

O Sindicato dos Bancários, no prazo estabelecido pelo Ministério do Trabalho, informou sua posição de rejeição ao projeto do governo e solicitou a constituição de uma Comissão Paritária para a elaboração de outro projeto (MOURA, 1989). Paralelamente às negociações com o governo, foram realizadas inúmeras reuniões da comissão de estudo dos bancários, que resultaram na formulação de um projeto alternativo.

Na primeira reunião, os bancários apresentaram um anteprojeto alternativo, com quatro pontos básicos: 1) aposentadoria aos cinqüenta anos de idade ou aos trinta anos de serviço; 2) estabilidade no emprego a partir do primeiro ano de serviço; 3) financiamento do Instituto tripartite: os bancos contribuiriam com três por cento da receita bruta, os bancários com contribuições médias entre três e cinco por cento dos salários e o governo faria aportes dos recursos equivalentes a três por cento dos lucros dos bancos; 4) caixa única e de caráter nacional.

Definiu-se que o projeto, depois de aprovado pela paritária, seria discutido pela categoria para ser aprovado em assembléias por todo o País (Correio da Manhã, 20/05/1934).

A formulação dos bancários surpreendeu os técnicos do Ministério do Trabalho e foi interpretada pelos bancários como um sinal positivo do governo. A ilusão se desfez logo e, na segunda reunião, os problemas recomeçaram. Os representantes do Ministério do Trabalho fizeram objeções a vários itens propostos: estabilidade após um ano; aposentadoria por invalidez; qualificação da mãe solteira e da companheira para o recebimento de benefícios, e outras restrições. Apesar disso, admitiam que o anteprojeto servia como base para a continuidade das negociações. Os bancários não aceitaram os vetos e as negociações caíram num impasse, só se solucionado com a greve nacional (MOURA, 1989).

Durante décadas houve uma intensa discussão sobre a abrangência de atendimento. Como já tivemos oportunidade de mencionar, ao contrário do projeto sindical, no projeto original os serviços assistenciais seriam atribuição dos sindicatos, não dos Institutos. Porém o ponto nevrálgico das disputas com o governo dizia respeito à gestão dos IAPs: “[...] Em 1937, o manifesto que apresentava o candidato a delegado-eleitor do Sindicato do Rio nas eleições para a Junta-Administrativa do Instituto, declarava: “O Instituto hoje já é uma grande realização. Precisamos, pois, não só mantêlo, mas aperfeiçoá-lo cada vez mais". E ainda: "O colega a quem devemos confiar tão espinhosa missão, precisa ser um bancário que, pela sua capacidade de administrar, possa colaborar para maior eficiência de nosso Instituto" (Bancário, jun./1943, p. 10-11).

No início da década de quarenta, o Conselho Atuarial, órgão do Ministério do Trabalho, apresentou o Plano Único de Previdência Social, que instituía uma taxa comum a todos organismos de previdência e a uniformização dos serviços e benefícios ${ }^{10}$. Como de resto ao longo de toda a história, o sindicato se opôs a qualquer interferência mais significativa do governo na gestão do IAPB, embora este indicasse o nome do presidente: "[...] a defesa de nossa máxima conquista, notadamente, no que diz respeito à administração do Instituto, onde reivindicamos para a classe uma parcela de responsabilidade em sua direção, ou seja, que a Junta Administrativa permanecesse

10 Trata-se do "Plano Único de Previdência Social" elaborado pelo Conselho atuarial que pretendia estatuir a taxa única para todos os organismos de previdência social e a uniformização dos serviços prestados. ("O plano único para as instituições de previdência social e os associados do Instituto de Aposentadorias e Pensões dos Bancários". Banćrio, mar./ 1941, p. 5). 
vazada nos moldes até então vigentes ao invés de passar à simples condição de um Conselho Fiscal. E no ofício que acompanhava nossas sugestões ao Ministro do Trabalho, podemos constatar o seguinte: 'Sendo o Instituto talvez o mais bem organizado, orgulhamo-nos de ter sido o mesmo criado, regulamentado e administrado, até a presente data, com a nossa estreita colaboração"” (Bancário, jun./1943, p. 10-11).

Apenas em 1956, já durante o governo Juscelino, é que os sindicatos conseguiram indicar o presidente do IAPB. A escolha de Enos Sadock de Sá Motta ${ }^{11}$ foi comemorada como uma grande vitória da categoria, a concretização do compromisso assumido por João Goulart durante o segundo governo Vargas. Durante a campanha eleitoral, por pressão de Jango, Juscelino comprometeu-se com a nomeação de um presidente para o IAPB indicado pelos sindicatos de bancários, e em troca recebeu o apoio à sua própria candidatura.

Após as eleições presidenciais, foi solicitado aos sindicatos apresentarem uma lista tríplice para a presidência do Instituto. A lista foi composta por um nome indicado por São Paulo, outro pelo Rio Grande do Sul e outro pelo Rio de Janeiro. O nome do Rio, escolhido por Juscelino, foi fruto de acordo entre a "Chapa Unidade Democrática" - com hegemonia do PCB - e vencedora das eleições para o sindicato, e as duas chapas vencidas, uma ligada a UDN e outra formada por setores independentes (LIMA, 1986, p. 65-66).

A gestão do primeiro presidente escolhido pelos sindicatos foi, certamente, a mais controvertida na história do Instituto. Acusado de corrupção pelos sindicatos liderados pela Confederação Nacional dos Trabalhadores em Empresas de Créditos - CONTEC - , foi alvo de uma forte campanha por sua destituição. Uma das denúncias foi contra a concordância de Enos Sadock de Sá Motta com a Portaria da Presidência da República cedendo os apartamentos de propriedade dos IAPs em Brasília aos servidores públicos federais. Os bancários consideraram que suas contribuições não poderiam transformar-se em benefícios para 11 Enos Sadock de Sá Motta, funcionário do Banco do
Brasil, foi interventor do Sindicato dos Bancários do Rio de
Janeiro de dezessete de abril de 1947 a dez de novembro de 1949 (Banćrio, mar/ 1953, p. 2). estranhos à classe. Diziam que o IAPB poderia construir em Brasília, ou em qualquer outra cidade brasileira, "mas as instalações, as casas, os apartamentos construídos deveriam ser ocupados pelos contribuintes da autarquia, que são seus legítimos beneficiários" (OLIVEIRA, 1959, p. 05).

Outro incidente ocorreu quando o Conselho Fiscal do IAPB, com o apoio do sindicato, vetou despacho do presidente autorizando construção de quinze unidades de "apartamentos de luxo" na cidade de São Borja. Segundo o Conselho, a cidade contava com sessenta e cinco bancários, a construção do edifício beneficiaria apenas quinze e, destes, nove teriam de possuir renda bem superior a média salarial dos bancários para poder arcar com as pesadas prestações. Assim, “[...] a construção do edifício é totalmente desaconselhável, por não estar de acordo com os objetivos da previdência social e também por não se enquadrar na realidade das condições locais [...]. É realmente penoso ter que repetir argumentos que foram objeto de demorado estudo e pronunciamento oficiais da classe bancária do país, principalmente por ocasião do VII Congresso Nacional. O Instituto dos Bancários não é, não pode ser, nunca deverá ser, companhia construtora de apartamentos caros, que dão belas fotografias mas nenhum proveito à massa de contribuintes. A Administração do Instituto deve, como tantas vezes lhe foi recomendada, tanto pelos órgãos sindicais como em inúmeras resoluções deste Conselho Fiscal, construir unidades residenciais econômicas, acessíveis à maioria, obedecendo o critério da densidade bancária de cada cidade [...]. O fato de ser São Borja a cidade natal do Sr. Vice-presidente da República, Dr. João Goulart, infunde à questão uma delicadeza especial [...]" ("Unidades Residenciais acessíveis à maioria em vez de apartamento de luxo". Bancário, fev/1959, p. 06).

A Confederação Nacional dos Trabalhadores em Empresas de Créditos - CONTEC - , por ocasião da sua reunião anual, realizada entre doze a quatorze de dezembro de 1958 , debateu a corrupção no IAPB na presença do próprio Enos Sadock de Sá. Foi apresentado um relatório sobre as irregularidades praticadas pela administração da autarquia, e cobrado do presidente, entre muitas outras coisas, o fato dele ter-se beneficiado com a aquisição de um apartamento, sem participar da concorrência a que estavam sujeitos os demais membros da categoria. No debate Enos Sadock de Sá respondeu "que tinha direito ao apartamento, 
porque contribuía para o Instituto há dezessete anos e vinha prestando ao IAPB dedicados serviços". O argumento foi considerado pelos dirigentes sindicais a confirmação de uma atitude de total desrespeito que não correspondia com "a confiança que lhe fora depositada pela classe" (Bancário, fev./1959, contra-capa).

Há uma infinidade de outras denúncias sobre a má utilização dos recursos da autarquia: cargos de diretores entregues a elementos estranhos ou a bancários de suas (do presidente do IAPB) relações pessoais sem consulta aos sindicatos; centenas de funcionários requisitados e à disposição de outros órgãos; centenas de nomeações; construções luxuosas, contrariando resoluções dos Congressos da categoria; apartamentos do Instituto locados a não bancários; empréstimos a entidades sem nenhuma relação com a categoria (como a Rádio Continental por exemplo); empréstimo de veículos do Instituto para outros órgãos; gastos exagerados em publicidade etc.

Porém, a crítica mais contundente e recorrente à gestão de Enos Sadock de Sá Motta, era o seu descaso com os órgãos da classe. "Sem qualquer referência à sua indicação pela classe bancária, nem às lutas da categoria pela melhoria da previdência". Reclamavam: não eram levadas em consideração as resoluções dos encontros da categoria, as demandas por maior participação dos dirigentes sindicais nas deliberações e nas decisões sobre a aplicação dos recursos. Enos Sadock de Sá Motta não compareceu à reunião nacional dos bancários de dezenove de junho de 1958, e sua participação foi chamada de "omissa" no VII Congresso Nacional dos Bancários onde não apresentou nem mesmo "um sucinto relatório". Desta forma, segundo os dirigentes bancários "[...] descumpria, assim, o colega Enos um dos itens da carta-compromisso que assinara por ocasião de sua indicação pelos bancários, pois obrigarase a comparecer a ditas reuniões sempre que solicitado" (Bancário, fev./1959, p. 16-23).

A avalanche de denúncias levou a Confederação Nacional dos Trabalhadores em Empresas de Créditos a promover uma série de reuniões com os representantes dos sindicatos e federações. Após muitos debates foi aprovada a moção pedindo o afastamento de Enos Sadock de Sá Motta: “[...] 2) - Solicitar imediato afastamento do atual Presidente do IAPB, tendo em vista que o referido senhor não mais merece a confiança dos bancários brasileiros e sua substituição por um dos integrantes da lista tríplice composta dos colegas Mílton Persivo, Haldane Teixeira e Osmildo Stafford" (Bancário, mai./1959, p. 02-03).

As denúncias ocuparam páginas e páginas da imprensa sindical e também da grande imprensa. A demissão de Enos Sadock de Sá e a indicação de novo presidente, no entanto, só se deu em dezembro de 1960. Foi então nomeado para presidir o Instituto um sindicalista bancário do Paraná, Edgar Rocha Costa, indicado em lista tríplice pelos sindicatos. Sua gestão foi saudada pelos sindicatos: "[...] Apoiamos de público as medidas moralizadoras e a nova política que a administração presidida pelo colega Edgard vem cumprindo em respeito aos mais puros anseios da classe bancária no campo da previdência social" (Bancário, jan./ 1961, p. 08).

A postura do novo presidente era bem diferente da anterior. Havia uma grande interação entre o gestor do IAPB e os sindicatos. O tom do discurso assume características sindicais e reivindicatórias, como fica bem expresso no caso da compra do Hospital da Lagoa 12: “[...] Convocamos o pessoal do Sindicato, do Conselho Fiscal e Administrativo do IAPB e representantes da classe médica do Instituto. Fizemos uma visita coletiva e concluímos a viabilidades da compra [...]. Foram quinze dias de conversa e [...], conseguimos reduzir o preço do hospital para quatrocentos e quarenta milhões [...]. Tudo acertado. Mas havia uma barreira: a burocracia. Assim, foi necessária uma grande mobilização dos bancários, que culminou com a entrega de um memorial ao presidente João Goulart com vinte mil assinaturas, colhidas em 48 horas" (Bancário, jan./1981, p. 07).

Esta vinculação era impensável no caso do IAPI e da maior parte dos outros Institutos. Em parte porque não estiveram ligados a apenas uma categoria profissional e, neste sentido, as próprias divergências sindicais reduziam o poder de pressão sobre o governo e o próprio Instituto.

No caso dos bancários, o maior poder de pressão gerou uma cobertura previdencial e assistencial bem mais aperfeiçoada. Neste sentido, os sindicatos não precisaram desenvolver grandes

12 Presidente do IAPB de 1955-1964 (Banćrio, jan./ 1981, p. 7). 
estruturas assistenciais. A análise de várias experiências diferenciadas permitiu, por exemplo, estabelecer uma relação entre sindicato politizado e atuante e instituto de previdência social eficiente; ou o inverso, sindicato menos atuante e mais assistencial, e instituto de previdência social mais ineficiente (COHN, 1980).

O depoimento de Lauro Jurandyr de Castro Leão, resume bem a postura dos dirigentes dos sindicatos bancários em relação ao IAPB. Demonstrando os vínculos estreitos, complexos e tensos entre estas duas organizações, tão raramente correlacionadas nas análises sobre sindicalismo: “[...] porque a gente tinha a nossa gente lá dentro, amigos e parentes, que a gente fazia onda, gritava. Tudo que saía errado lá, a gente tomava conhecimento e botava a boca no mundo através do sindi- cato. A gente gritava, e sempre alguém ouvia, né? Então, eles mordiam, mas mordiam de leve, está entendendo?" (LEÃO, 1986, p. 52).

No caso, julgamos poder estar entendendo, ao menos, entendendo um pouco melhor. A construção do IAPB teve forte relação com as razões que levaram os bancários a adequarem-se à lei de sindicalização de 1931: a falta de proteção social. E expressou junto com a construção do sindicalismo corporativo praticado pelos bancários, a consolidação de uma categoria profissional singular em relação aos demais trabalhadores, fortemente baseada na auto-imagem de trabalhador mais qualificado, de quem era exigido um determinado padrão social e cultural.

Recebido para publicação em agosto de 1998.

Ana Lúcia Valença de Santa Cruz Oliveira (escaletsky @ax.apc.org) é Doutora em História e Professora Adjunta da Universidade Federal Rural do Rio de Janeiro (UFRRJ).

\section{REFERÊNCIAS BIBLIOGRÁFICAS}

ALMEIDA, M. H. T. 1975. O sindicato no Brasil; novos problemas, velhas estruturas. Debate e Crítica, São Paulo, n. 6, p. 49-74, jul.

. 1978. Estado e classes trabalhadoras no Brasil : 1930-1945. Tese de Doutorado. FFLCH/USP. São Paulo.

1983. A revolução de 30 e a questão sindical. In: Revolução de 30: seminário internacional. Brasília/Rio de Janeiro : Editora da UnB/CPDOC-FGV.

BARCELLOS, T. M. M. de (org). 1983. A política social brasileira : 1930-64. Porto Alegre : FEE.

BLASS, L. M. da S. 1992a. Estamos em greve : imagens, gestos e palavras do movimento dos bancários. São Paulo : Hucitec/Sindicato dos Bancários de São Paulo.

1992b. Automação bancária : práticas e representações. Caxambu, XVI Encontro Anual da ANPOCS, outubro. Mimeo.

CANÊDO, L. B. 1978. O sindicalismo bancário em São Paulo. São Paulo : Símbolo.

1986. Bancários : movimento sindical e participação política. Campinas : Ed. da
Unicamp.

COHN, A. 1980. Previdência social e processo político no Brasil. São Paulo : Moderna.

DEPARTAMENTO INTERSINDICAL DE ESTATÍSTICA E ESTUDOS SÓCIOECONÔMICO. 1980. Profissão: Bancário. Perfil da categoria. Estudos Socioeconômicos, São Paulo, 5.

ERICKSON, P. 1970. Labour in Political Process in Brazil: Corporation in Modernizing Nation. $\mathrm{PhD}$ Thesis. Nova York, Columbia University.

GOMES, A. M. de C. 1983. Empresariado e legislação social na década de 30. In: Revolução de 30: seminário internacional. Brasília/ Rio de Janeiro : Editora da UnB/CPDOC-FGV. 1988. A invenção do trabalhismo. São Paulo/Rio de Janeiro : Vértice/IUPERJ.

GRUN, R. 1986. Taylorismo e fordismo no trabalho bancário : agentes e cenários. Revista Brasileira de Ciências Sociais, São Paulo, vol. 2, n. 1 , p. 13-27, out.

HOCHMAN, G. 1988. Aprendizado e difusão na constituição de política: a Previdência Social e seus técnicos. Revista Brasileira de Ciências 
Sociais, São Paulo, vol.3, n. 7, p. 84-98, jun.

1990. De inapiários a cardeais da previdência social : a lógica da ação de uma elite burocrática. Dissertação de Mestrado. Rio de Janeiro, IUPERJ. Mimeo.

ISUANI, E. A. 1985. Los orígenes conflictivos de la seguridad social argentina. Buenos Aires: Centro Editor de América Latina.

KAREPOVS, D. (coord.). 1994. A história dos bancários : lutas e conquistas (1923-1993). São Paulo: Sindicato dos Bancários e Financiários de São Paulo.

MALLOY, J. M. s/d. Previdência social e distribuição de renda: notas de pesquisa. Estudos CEBRAP, São Paulo, n. 25, p. 113-133.

1976. Previdência social e classe operária no Brasil. Estudos CEBRAP, São Paulo, n. 15, p. $115-131$.

MELLO, C. G. 1981. Assistência médica e previdência social - o que está por trás do fracasso. Bancário, Rio de Janeiro, nº 374 , fev.
OLIVEIRA, A. L. V. S. C. 1990. Sindicalismo bancário : origens. Rio de Janeiro : Oborél Sindicato dos Empregados em Estabelecimentos Bancários do Rio de Janeiro.

1998. Sindicato e sindicalismo bancário. Seropédica : Edur.

OLIVEIRA, J. A A \& TEIXEIRA, S. M. F. 1986. IMPrevidência social : 60 anos de história da Previdência no Brasil. Petrópolis/Rio de Janeiro : Vozes/Associação Brasileira Pós-Graduação em Saúde Coletiva.

OLIVEIRA, W.1959. O IAPB — de Brasília a Londres. Bancário, Rio de Janeiro, $\mathrm{n}^{\circ} 1$, jan.

ROMANELLI, G. 1978. O provisório definitivo - trabalho e aspirações de bancários em São Paulo. Dissertação de Mestrado. São Paulo, FFLCH/USP.

SEGNINI, L. 1988. A liturgia do poder : trabalho e disciplina. São Paulo : Educ.

SINDICATO DOS BANCÁRIOS DE SÃO PAULO. s/d. Luta, organização e consciência dos bancários. São Paulo : SEEB-SP.

\section{OUTRAS FONTES}

\section{Jornais e Revistas}

Bancário. Rio de Janeiro : 1941; 1943; 1953; 19581959; 1961; 1967; 1981.

Correio da Manhã, Rio de Janeiro, 1934.

\section{Documentos Oficiais}

BRASIL. Decreto no 19.770, de 19 de março de 1931. 1933. Regula a sindicalização das classes patronais e operárias e dá outras providências. Legislação Social Trabalhista, Rio de Janeiro.

BRASIL. Decreto $\mathrm{n}^{\circ} 24.615$, de 9 de julho de 1934. 1935. Cria e Regulamenta o IAPB. Ministério do Trabalho, Indústria e Comércio. Rio de Janeiro.

BRASIL. Decreto $\mathrm{n}^{\circ}$ 54, de 12 de setembro de
1934. 1935. Cria e Regulamenta o IAPB. Ministério do Trabalho, Indústria e Comércio. Rio de Janeiro.

BRASIL. Lei n ${ }^{\circ}$ 367, de 31 de dezembro de 1936.

INSTITUTO DE APOSENTADORIAS E PENSÕES. Ministério do Trabalho Indústria e Comércio. 1935. Rio de Janeiro, Departamento de Estatística e Publicidade.

\section{Depoimentos}

LEÃO, L. J. C. 1986. Depoimento. Fiocruz/COC/ Programa de História Oral.

LIMA, L. V. M. 1986. Depoimento. Fiocruz/COC/ Programa de História Oral.

MOURA, A. 1983-1989 Depoimentos. Rio de Janeiro. 